the Anna Fuller Fund and the National Cancer Institute of the National Institutes of Health, U.S. Public Health Service.

\section{REFERENCES}

Crampton, C. F., Stein, W. H. \& Moore, S. (1957). J. biol. Chem. 225, 363.

Cruft, H. J., Hindley, J., Mauritzen, C. M. \& Stedman, E. (1957a). Nature, Lond., 180, 1107.

Cruft, H. J., Mauritzen, C. M. \& Stedman, E. (1957b). Phil. Trans. B, 241, 93.

Davison, P. F., James, D. W. F., Shooter, K. V. \& Butler, J. A. V. (1954). Biochim. biophys. Acta, 15, 415.

Hnilica, L., Johns, E. W. \& Butler, J. A. V. (1962). Biochem. J. 82, 123.
Johns, E. W. \& Butler, J. A. V. (1962). Biochem. J. 82, 15. Johns, E. W., Phillips, D. M. P., Simson, P. \& Butler, J. A. V. (1960). Biochem. J. 77, 631.

Johns, E. W., Phillips, D. M. P., Simson, P. \& Butler, J. A. V. (1961). Biochem. J. 80, 189.

Mirsky, A. E. \& Pollister, A. W. (1942). Proc. nat. Acad. Sci., Wash., 28, 344.

Phillips, D. M. P. (1958). Biochem. J. 68, 35.

Phillips, D. M. P. \& Johns, E. W. (1959). Biochem. J. 72, 538.

Phillips, D. M. P. \& Simson, P. (1962). Biochem. J. 82, 236.

Sanger, F. (1945). Biochem. J. 39, 507.

Ui, N. (1957). Biochim. biophys. Acta, 25, 493.

Vendrely, R., Knobloch-Mazen, A. \& Vendrely, C. (1960). Biochem. Pharmacol. 4, 19.

\title{
A Method for the Determination of Cystine plus Cysteine in Proteins
}

\author{
By J. C. FLETCHER AND A. ROBSON \\ Wool Industries Research Association, Torridon, Headingley, Leeds 6
}

(Received 6 March 1962)

At the present time, the determination of the amino acid composition of a protein offers few difficulties. Only cysteine, cystine and tryptophan provide exceptions to this general statement. Cystine and cysteine suffer variable and often considerable destruction during acid hydrolysis, and tryptophan is almost completely destroyed. Several approaches have been adopted to circumvent this difficulty with cystine and cysteine. Schram, Moore \& Bigwood (1954) oxidized the half-cystine residues to cysteic acid residues before hydrolysing the protein. Thompson (1955) carried out the oxidation with bromine after a partial acid hydrolysis. Several workers (Kolthoff, Anastasi \& Tan, 1958; Human, 1958; Cecil \& Loening, 1960; Leach, $1960 a, b)$ sought to determine disulphide and thiol groups in intact proteins with reagents, such as monofunctional mercurials, that react specifically with thiol groups, the cystine being first reduced; this approach is important because, in addition to determining total thiol plus disulphide, it can provide information about the reactivities of individual residues. The colorimetric method of Glazer \& Smith (1961) combines partial acid hydrolysis with disulphide interchange between protein cystine and cysteine and bis(dinitrophenyl)cystine. Although for most proteins these various methods give concordant results, there are still several well-characterized proteins for which the number of half-cystine residues is not known with certainty.

The method described below had its origin in an investigation of the sulphur balance of wool keratin and, in particular, the discrepancy between the chromatographic and colorimetric estimations for the cystine content of wool hydrolysates (Corfield \& Robson, 1955). In a general attack on this problem, ${ }^{35} \mathrm{~S}$-labelled wool was obtained by oral administration of $\left[{ }^{35} \mathrm{~S}\right]$ sulphate to a sheep, and hydrolysates of this wool were examined by chromatography on starch columns (Lewis, Robson \& Tiler, 1960). The hydrolysates were found to contain, in addition to cystine and methionine, several other ${ }^{35}$ S-labelled substances, which together accounted for about $10 \%$ of the total activity. One of these substances was identified as cysteine. In an effort to find out whether these compounds were produced by the decomposition of cystine during hydrolysis, or whether they were derived from other sulphur-containing moieties in the original wool, unlabelled wool was hydrolysed in the presence of $\left.{ }^{35} \mathrm{~S}\right]$ cystine. Chromatography of the resulting hydrolysate showed that, though the distribution of ${ }^{35} \mathrm{~S}$-labelled peaks was not as complex as that given by the ${ }^{35}$ S-labelled wool hydrolysate, the major unidentified peaks were common to both chromatograms; it thus appears that the greater part of the 'missing' sulphur in wool hydrolysates is present as compounds which are derived from cystine. The formation of these compounds does not merely involve a straightforward breakdown of cystine under acid conditions, as they are not formed when $\left[{ }^{35} \mathrm{~S}\right]$ cystine alone is boiled with acid. The specific activities of the 
sulphur in these compounds is, within the limits of experimental error, the same as that of the cystine, i.e. the cystine in a wool hydrolysate and all its decomposition products, including cysteine, become uniformly labelled if hydrolysis is carried out in the presence of $\left.{ }^{35} \mathrm{~S}\right]$ cystine. This suggested that the true cystine-plus-cysteine content of the original wool might be determined by adding a known activity of [ $\left.{ }^{35} \mathrm{~S}\right]$ cystine to a known weight of wool, hydrolysing, isolating cystine from the hydrolysate, and determining the specific activity of the cystine. The method should also be applicable to other proteins.

The ${ }^{35} \mathrm{~S}$-labelled compounds are conveniently separated on the cation-exchange resin Zeo-Karb 225 in the hydrochloric acid solvent system of Stein \& Moore (1950); difficulties due to the presence of buffer salts are thus avoided. In the preliminary work on the specific activities of cystine and its decomposition products in wool hydrolysates, it was necessary to make elementary analyses for sulphur. In applying the method to proteins, however, we have used for the determination of cystine the rapid and specific phosphotungstic acid reduction method originally due to Folin \& Marenzi (1929a).

This paper describes the method and gives the results obtained with certain pure proteins. A preliminary account of this work has appeared (Fletcher \& Robson, 1961).

\section{MATERIALS AND METHODS}

Cystine. This was Laboratory Reagent grade (British Drug Houses Ltd.) recrystallized from $\mathrm{HCl}$ according to Toennies \& Lavine (1930). Fraction II had $[\alpha]_{\mathrm{D}}^{18 \cdot 5^{\circ}}-229^{\circ}$ (c 0.92 in $\mathrm{N}-\mathrm{HCl})$.

Cysteine. This was Fluka Chromatographically Pure grade.

DL- $\left.{ }^{35} \mathrm{~S}\right]$ Cystine. This was obtained from The Radiochemical Centre, Amersham. The radiochemical purity was checked by chromatography (specific activity, $48 \mathrm{mc}$ / m-mole).

Australian Merino 64s-quality wool. This was prepared according to Corfield \& Robson (1955). It was 'conditioned' over saturated $\mathrm{NH}_{4} \mathrm{NO}_{3}$ soln., and the moisture content determined by drying samples at $105^{\circ}$.

Other proteins. Insulin (five-times recrystallized, batch CBI 5151S) was supplied by Boots Pure Drug Co. Ltd. Lysozyme and bovine plasma albumin were crystalline preparations supplied by British Drug Houses Ltd. and L. Light and Co.Ltd. respectively. These proteins were dried in vacuo over $\mathrm{P}_{2} \mathrm{O}_{5}$.

De-ionized water was used in making up all solutions.

Specific activities of the ${ }^{35} \mathrm{~S}$-labelled compounds formed when wool is hydrolysed in the presence of $\left[{ }^{35} \mathrm{~S}\right]$ cystine

Wool (10 g.) was hydrolysed for $48 \mathrm{hr}$. in $200 \mathrm{ml}$. of $5 \cdot 7 \mathrm{~N}-\mathrm{HCl}$ containing approx. $1 \mathrm{mc}$ of $\left.{ }^{35} \mathrm{~S}\right]$ cystine. The $\mathrm{HCl}$ was removed in vacuo in a stream of $\mathrm{N}_{2}$. One-tenth of the residue, in $10 \mathrm{ml}$. of $1.5 \mathrm{~N}-\mathrm{HCl}$, was applied to a column
(4 cm. $\times 46 \mathrm{~cm}$.) of Zeo-Karb 225 (X4), and chromatographed in the HCl solvent system of Stein \& Moore (1950). Fractions of $25 \mathrm{ml}$. were collected. A portion $(0.5 \mathrm{ml}$.) of each fraction was evaporated to dryness on a small polythene dish and the residue assayed for approximate ${ }^{85} \mathrm{~S}$ activity with an end-window Geiger-Müller counter. The fractions contributing to each ${ }^{35} \mathrm{~S}$-activity peak were combined and evaporated to dryness in a stream of $\mathrm{N}_{2}$. The residues were dissolved in water and the solutions assayed for total $S$ and ${ }^{35} \mathrm{~S}$ activity. Total $\mathrm{S}$ and ${ }^{35} \mathrm{~S}$-activity determinations were also made on the original hydrolysate.

Total sulphur. This was determined by the method of Jones \& Letham (1956).

${ }^{85} \mathrm{~S}$ activity. The ${ }^{85} \mathrm{~S}$ from the ${ }^{35} \mathrm{~S}-$-labelled compounds was incorporated into benzidine sulphate for assay of activity according to Henriques, Kistiakowsky, Margnetti \& Schneider (1946). At least three and usually four samples were counted.

\section{Determination of cystine plus cysteine in proteins}

(a) Protein (25-100 mg.), depending on the cystine content, was refluxed for $16-40 \mathrm{hr}$. with $20 \mathrm{ml}$. of $5 \cdot 7 \mathrm{~N}-\mathrm{HCl}$ (prepared from Microanalytical Reagent $\mathrm{HCl}$, from British Drug Houses Ltd.) containing approx. $10 \mu \mathrm{C}$ of [ $\left.{ }^{35} \mathrm{~S}\right]$ cystine. (b) In one case, the protein was hydrolysed in $10 \mathrm{ml}$. of $10 \mathrm{~N}-\mathrm{HCl}$, containing $\left[{ }^{35} \mathrm{~S}\right]$ cystine, for 5 days at $37^{\circ}$, followed by dilution of the acid to $5 \cdot 7 \mathrm{~N}$, and refluxing for $24 \mathrm{hr}$.

Chromatography. The hydrolysate was evaporated in vacuo and the residue, dissolved in $2.5 \mathrm{~N}-\mathrm{HCl}$, was chromatographed in this solvent on a $0.9 \mathrm{~cm} . \times 40 \mathrm{~cm}$. or a $1.8 \mathrm{~cm} . \times 40 \mathrm{~cm}$. column of Zeo-Karb 225 (X4), according to the weight of protein taken. A portion $(0 \cdot 1 \mathrm{ml}$.) was removed from each fraction (3 or $10 \mathrm{ml}$.) and evaporated on a polythene tray for location of peaks by determination of approximate ${ }^{35} \mathrm{~S}$ activity. From these columns the cysteine and cystine peaks emerged at about fraction numbers 17 and 29 respectively. The fractions contributing to the cystine peak and, if desired, the cysteine peak, were combined and evaporated to dryness, and the residue was dissolved in $0.4 \mathrm{~N}-\mathrm{HCl}$. The ${ }^{35} \mathrm{~S}$ activity was determined on diluted portions of this solution and of the $\left[{ }^{35} \mathrm{~S}\right]$ cystine solution added before hydrolysis.

Determination of cystine and cysteine. For the determination of cystine, $1 \mathrm{ml}$. of the $0.4 \mathrm{~N}-\mathrm{HCl}$ solution containing not more than $150 \mu \mathrm{g}$. of cystine was run into a $10 \mathrm{ml}$. volumetric flask. To this were added, in the following order, with mixing, $2 \mathrm{ml}$. of acetate buffer, pH 5.2 $(25 \mathrm{ml}$. of acetic acid and $300 \mathrm{~g}$. of sodium acetate trihydrate/1.), $0.6 \mathrm{ml}$. of $\mathrm{N}$-sodium hydrogen sulphite and $0.8 \mathrm{ml}$. of phosphotungstic acid reagent (Folin \& Marenzi, 1929b), and the flask was filled to the mark with water. After $30 \mathrm{~min}$. the extinction at $890 \mathrm{~m} \mu$ was read against water in a $1 \mathrm{~cm}$. cell (Unicam SP. 500 spectrophotometer). The blue colour is stable for many hours. Usually four, and never less than three, replicates were done. For the determination of cysteine the procedure was the same, except that sodium hydrogen sulphite was omitted.

Linear plots, prepared with cystine and cysteine standards, gave the relations:

$$
\begin{aligned}
& \mu \mathrm{g} \text {. of cystine } \mathrm{S}=70.0\left(E_{\mathrm{Cy}_{2} \mathrm{~S}_{2}}-0.027\right) \\
& \mu \mathrm{g} \text {. of cysteine } \mathrm{S}=67.3 E_{\mathrm{CySH}}
\end{aligned}
$$

and from these the amounts of cystine and cysteine present could be calculated. The ratio of the colour intensities 
given by cysteine in the presence and absence of bisulphite was found to be 1.84 and not 2.00 as would be expected on theoretical grounds. For mixtures of cystine and cysteine, therefore, the cystine $S$ is calculated from the relation:

$\mu \mathrm{g}$.of cystine $\mathrm{S}=70 \cdot 0\left[\left(E_{\mathrm{O}_{2} \mathrm{~S}_{2}}-0.027\right)-\left(1 \cdot 84 E_{\mathrm{CySH}}\right)\right]$

Calculation of cystine-sulphur plus cysteine-sulphur content of protein. If $x$ is the activity per unit volume of the $\left[{ }^{35} \mathrm{~S}\right]$ cystine solution added to the hydrolysate, and $y$ is the activity of that fraction of the cystine isolated by chromatography which corresponds to this unit volume, then

( $\mu \mathrm{g}$. of cystine $\mathrm{S}+$ cysteine $\mathrm{S})=(\mu \mathrm{g}$. of $\mathrm{S}$ in cystine peak) $x / y$

This assumes that the $\left[{ }^{35} \mathrm{~S}\right]$ cystine added contributes a negligible amount of cystine S. This was usually the case, but in some of the later analyses, where larger amounts of $\left[{ }^{35} \mathrm{~S}\right]$ cystine had to be used because of radioactive decay, a correction of $w y / x$, where $w$ is the weight of sulphur added as $\left[{ }^{35} \mathrm{~S}\right]$ cystine, was subtracted from the chromatographically determined cystine $\mathrm{S}$. This correction was never greater than 2-3\%.

\section{RESULTS}

\section{Stability of cystine in acid solution}

Shinohara \& Kilpatrick (1934) reported that at room temperature traces of cysteine can be detected in aged solutions of cystine in $0.2 \mathrm{~N}$ hydrochloric acid by the initial rate of reaction with iodine. In a batch of $\left[{ }^{35} \mathrm{~S}\right]$ cystine used in previous work (Lewis et al. 1960) about $1 \%$ of the activity was present as cysteine after the solution in $0.1 \mathrm{~N}$-hydrochloric acid had stood for 81 days at $4^{\circ}$. The batch of $\left.{ }^{35} \mathrm{~S}\right]$ cystine used in the present work, however, after standing in $0.1 \mathrm{~N}$-acid up to 155 days at room temperature, gave no significant peaks other than cystine on chromatography. Comparatively high activities were chromatographed for purification purposes, and less than $0.003 \%$ of the activity appeared as cysteine. Aged solutions of $\left[{ }^{35} \mathrm{~S}\right]$ cystine in $5 \cdot 7 \mathrm{~N}$-acid, on the other hand, contain a labelled substance that runs as a peak on the solvent front when chromatographed in 2.5 N-hydrochloric acid on Zeo-Karb 225. After the solution had aged for 56 days, this peak contained $13 \%$ of the total counts. When such a solution of $\left.{ }^{35} \mathrm{~S}\right]$ cystine is used for the hydrolysis of a protein, the solvent-front peak is not present on the chromatogram of the hydrolysate: it cannot therefore be due to cysteic acid or inorganic sulphate. If the $\left[{ }^{35} \mathrm{~S}\right]$ cystine solution is refluxed in the absence of protein for a similar period, the peak is still present. The use of aged solutions of $\left[{ }^{35} \mathrm{~S}\right]$ cystine in $5 \cdot 7 \mathrm{~N}$-acid for the determination of cystine plus cysteine appears to give reliable results, and the unknown substance must therefore exchange its sulphur with cystine: it has not yet been further investigated. In view of these findings, the [ $\left.{ }^{35} \mathrm{~S}\right]-$ cystine standard solution was made up in $0.1 \mathrm{~N}$ - hydrochloric acid and mixed with an equal volume of hydrochloric acid (Microanalytical Reagent) immediately before use.

Specific activities of the ${ }^{35} \mathrm{~S}$-labelled compounds formed when wool is hydrolysed in the presence of $\left[{ }^{35} \mathrm{~S}\right]$ cystine

The plot of approximate ${ }^{35} \mathrm{~S}$ activity (polythenetray method) against fraction numbers obtained by chromatography of the hydrolysate is shown in Fig. 1, in which, owing to the different weights of the amino acids in the fractions, the number of counts in the peaks are an approximate indication of their sulphur contents. The specific activities and sulphur contents of the peaks and of the hydrolysate are shown in Table 1 . Peak 3 was not analysed because of its small size, and also because methionine emerges in this region of the chromatogram. For peaks 8 and 9 the combined material from three runs were used for the analysis, and the working-up of comparatively large volumes of solvent, which may contain traces of inactive sulphur, is probably responsible, at least in part, for the lower specific activities found for these two peaks. The weightedmean specific activity of the non-cystine sulphur is $5.3 \times 10^{4}$ counts/min./mg., which, in view of the manipulations involved, we consider to be in reasonable agreement with the value $5.7 \times 10^{4}$ counts/min./mg. for the cystine peak and the hydrolysate.

\section{Cystine-plus-cysteine sulphur in proteins by the ${ }^{35} \mathrm{~S}$ method}

The results obtained with insulin, lysozyme and bovine plasma albumin are given in Table 2 . The

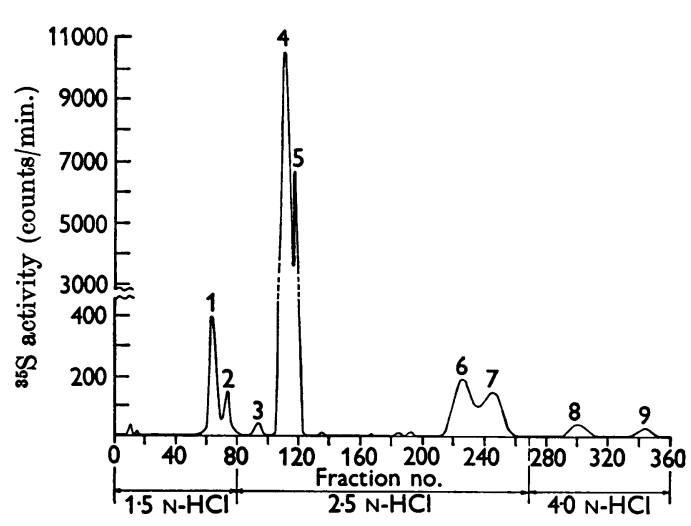

Fig. 1. Chromatography of the ${ }^{35} \mathrm{~S}$-labelled compounds formed when wool is hydrolysed in the presence of $\left[{ }^{35} \mathrm{~S}\right]$ cystine. A column $(4 \mathrm{~cm} . \times 46 \mathrm{~cm}$.) of Zeo-Karb $225(\mathrm{X} 4)$ resin was used. The load was hydrolysate from $1 \mathrm{~g}$. of wool and $100 \mu \mathrm{c}$ of ${ }^{[35}$ ] $]$ cystine. The fraction size was $25 \mathrm{ml}$; $0.5 \mathrm{ml}$. samples were taken for assay of ${ }^{35} \mathrm{~S}$. Peak 1 is cysteine, peaks 4 and 5 are cystine and mesocystine; other peaks are unidentified. 
results for insulin are corrected to the theoretical nitrogen content, which corresponds to $5 \%$ of residual moisture in the protein after prolonged drying in vacuo over phosphorus pentoxide at room temperature. In the last column of Table 2 are given the values calculated from the known structures of insulin and lysozyme, and recent experimental values, assuming a mol.wt. of 69000 , for bovine plasma albumin. The results obtained by the present method are within 3-4\% of these values. The present results for lysozyme indicate the presence of eight half-cystine residues/mole, as required by the formula of Jollès, Jollès \& JaureguiAdell (1960). Glazer \& Smith (1961) found ten halfcystine residues/mole, as was reported by Anfinsen

Table 1. Specific activities of the ${ }^{35} \mathrm{~S}$-labelled compounds formed when wool is hydrolysed in the presence of $\left[{ }^{35} \mathrm{~S}\right]$ cystine

The results refer to $1 \mathrm{~g}$. of wool hydrolysed for $48 \mathrm{hr}$. in 5.7N-HCl. The ${ }^{35} \mathrm{~S}-$ labelled compounds were separated by chromatography, details of which are given in Fig. 1. The methods used for the determination of total $S$ and ${ }^{25} S$ activity are described in the Materials and Methods section.

$\begin{array}{ccc}\text { No. of peak in Fig. } 1 & \begin{array}{c}10-4 \times \text { Sp. } \\ \text { activity } \\ \text { (mg.) }\end{array} & \begin{array}{c}\text { (counts } / \text { min./ } \\ \text { mg. of S) }\end{array} \\ 1 & 0.96 & 4 \cdot 5 \\ 2 & 0 \cdot 45 & 5 \cdot 1 \\ (4+5)^{*} & 27 \cdot 0 & 5 \cdot 7 \\ 6 & 0.97 & 5 \cdot 8 \\ 7 & 0 \cdot 91 & 5 \cdot 5 \\ 8 & 0.34 & 4 \cdot 5 \\ 9 & 0 \cdot 22 & 3 \cdot 7 \\ \text { Original hydrolysate } & 31 \cdot 6 & 5 \cdot 7 \\ & \text { * Cystine and mesocystine. }\end{array}$

(1958) and earlier workers (Lewis, Snell, Hirschmann \& Fraenkel-Conrat, 1950; Fromageot \& de Garilhe, 1950).

The conditions of hydrolysis do not appear to be critical. The preliminary treatment in $10 \mathrm{~N}$-acid used in one of the lysozyme determinations was intended to facilitate disulphide interchange (Glazer \& Smith, 1961).

\section{Errors}

The method of Henriques et al. (1946) used for counting ${ }^{35} \mathrm{~S}$ gives very reproducible results. All samples were counted to at least $10^{4}$ total counts, and ${ }^{35} \mathrm{~S}$ standards were counted before and after the samples. The error in counting should therefore not be greater than $1 \%$. The error in the spectrophotometric determination of cystine is approximately $2 \%$. Thus the expected experimental error of the method is $2-3 \%$.

Systematic errors could arise from a departure from the assumed uniformity of ${ }^{35} \mathrm{~S}$ labelling of all the sulphur compounds derived from cystine. If volatile sulphur compounds are lost from the hydrolysate before uniform labelling is attained, the method would give low results. On the other hand, loss of ${ }^{35} \mathrm{~S}$ activity due to the decomposition of [ $\left.{ }^{35} \mathrm{~S}\right]$ cystine to give volatile sulphur compounds with specific activities higher than the equilibrium value would lead to high results. A $16 \mathrm{hr}$. insulin hydrolysate was found to contain $99 \%$ of the activity originally added : after $40 \mathrm{hr}$. hydrolysis the value had fallen to $94 \cdot 2 \%$. For wool hydrolysates, which have a characteristic 'sulphurous' odour, the values at corresponding times were 97.6 and $93.9 \%$ (means of four hydrolysates). This small loss of volatile ${ }^{35} \mathrm{~S}$ during the first $16 \mathrm{hr}$. of the hydrolysis definitely limits the second type of systematic error.

\section{Table 2. Cystine sulphur plus cysteine sulphur in proteins}

Protein (25-100 mg.) was hydrolysed under the conditions stated in the presence of [ $\left.{ }^{35 S}\right]$ cystine (10 $\left.\mu \mathrm{C}\right)$. Cystine was isolated by chromatography of the hydrolysate on $40 \mathrm{~cm}$. columns of Zeo-Karb 225 (X4). For details of the determination of the specific activity of the cystine, and the calculation of the cystine-S plus cysteine-S contents of the proteins, see text.

\begin{tabular}{|c|c|c|c|}
\hline Protein & Conditions of hydrolysis & $\begin{array}{l}\text { Cystine S in } \\
\text { hydrolysate } \\
(\%)\end{array}$ & $\begin{array}{c}\text { Cystine S + } \\
\text { cysteine S } \\
(\%)\end{array}$ \\
\hline Insulin & $\begin{array}{l}16 \mathrm{hr} \text {. reflux in } 5 \cdot 7 \mathrm{~N} \cdot \mathrm{HCl} \\
40 \mathrm{hr} \text {. reflux in } 5 \cdot 7 \mathrm{~N}-\mathrm{HCl}\end{array}$ & $\begin{array}{l}2 \cdot 88 \\
2 \cdot 81 \\
2 \cdot 89 \\
\mathbf{3} \cdot 02\end{array}$ & $\begin{array}{l}3 \cdot 41 \\
3 \cdot 54 \\
3 \cdot 39 \\
3 \cdot 34\end{array}$ \\
\hline Lysozyme & $\begin{array}{l}40 \mathrm{hr} \text {. reflux in } 5 \cdot 7 \mathrm{~N}-\mathrm{HCl} \\
5 \text { days at } 37^{\circ} \text { in } 10 \mathrm{~N}-\mathrm{HCl} \text {, } \\
\text { followed by } 24 \mathrm{hr} \text {. reflux } \\
\text { in } 5.7 \mathrm{~N}-\mathrm{HCl}\end{array}$ & $\begin{array}{l}1 \cdot 21 \\
1 \cdot 00 \\
0 \cdot 52^{*}\end{array}$ & $\begin{array}{l}1 \cdot 72 \\
1 \cdot 73 \\
1 \cdot 78^{*}\end{array}$ \\
\hline Bovine plasma albumin & $24 \mathrm{hr}$. reflux in $5 \cdot 7 \mathrm{~N}-\mathrm{HCl}$ & $1 \cdot 48$ & 1.59 \\
\hline
\end{tabular}

(Kolthoff et al. 1957,
$1958) \quad 1.60$
(Leach, 1960 a)
1.62

* Refers to cysteine peak.

(Glazer \& Smith, 1961) 


\section{DISCUSSION}

Although this method is based on results obtained with wool keratin, a protein of doubtful homogeneity, it has nevertheless given results in good agreement with theoretical or accepted experimental values for the three well-characterized proteins insulin, lysozyme and bovine plasma albumin. This substantiates the soundness of the basic assumption that all the sulphur compounds derived from cystine or cysteine become uniformly labelled when a protein is hydrolysed in the presence of $\left[{ }^{35} \mathrm{~S}\right]$ cystine. The process may merely involve the decomposition of free cystine under the influence of other substances present in the hydrolysate; or peptide-bound cystine residues may undergo reaction, and subsequently become labelled by disulphide interchange with free cystine. At room temperature, disulphide interchange is slow at the concentration of acid used in the presence of traces of thiol (Ryle \& Sanger, 1955). If exchange plays a part, it must be sufficiently rapid at the boiling point of $5 \cdot 7 \mathrm{~N}$-hydrochloric acid for equilibrium to be attained. As yet, no experimental evidence bearing on the mechanisms involved has been obtained.

The method is time-consuming and not suitable for routine work. For work with certain sulphurcontaining proteins of technological importance, such as wool, in which large numbers of cystine analyses are currently done on hydrolysates, it may be possible to use methods such as the present one to standardize, empirically, other methods for cystine determination, e.g. the phosphotungstic acid method, which are suitable for routine and serial analyses. To this end, importance is attached to the combined investigation of accurate cystineplus-cysteine values, the distribution of sulphur compounds in hydrolysates, and the results of more rapid methods of analysis.

Although the cystine peak is usually the only one which is sufficiently large to make the analysis practicable, hydrolysates of proteins with high tryptophan contents, such as lysozyme, give cysteine peaks that are about $50 \%$ of the size of the cystine peak. During the removal of acid from cysteine solutions, a small amount of the cysteine becomes oxidized to cystine, and it is necessary to analyse for both thiol and disulphide under conditions where the phosphotungstic acid method is least accurate. For this reason we regard results obtained from the cysteine peak as having only confirmatory value.

Any other specific method, e.g. a polarographic one, could be substituted for the phosphotungstic acid method in the analysis of the cystine peak. We have used the latter method because it is rapid and gives accurate results on clean cystine solutions, reproducible within the error of spectro- photometric measurement. We are less certain of the errors involved in the direct application of our simple version of this method to protein hydrolysates. Much careful work has been done on the problem of extraneous reducers by Shinohara (1936), Kassell \& Brand (1938) and Kolb \& Toennies (1952). We have, however, repeatedly confirmed that, under the conditions described, cysteine gives less than the theoretical increase of $100 \%$ in colour intensity on the addition of bisulphite.

Quantitative recovery of cystine is not theoretically necessary in the method, provided that the amount of inactive cystine added with the [ $\left.{ }^{35} \mathrm{~S}\right]$ cystine is negligible. However, because of our interest in the chromatographic cystine values, we have always taken the whole of the cystine peak for the analysis. The possibility of isotopic fractionation on the column (Piez \& Eagle, 1956) must also be borne in mind.

\section{SUMMARY}

1. When wool is hydrolysed in the presence of $\left[{ }^{35} \mathrm{~S}\right]$ cystine, all the ${ }^{35} \mathrm{~S}$-labelled compounds present in the hydrolysate are found to have the same specific activity.

2. A method of determining cystine sulphur plus cysteine sulphur in proteins is described: the protein is hydrolysed in the presence of $\left.{ }^{35} \mathrm{~S}\right]$ cystine, and the cystine in the hydrolysate is isolated by chromatography and its specific activity determined. Then:

$$
\begin{aligned}
& \text { Cystine } S+\text { cysteine } S \\
& =\frac{\text { total activity added before hydrolysis }}{\text { specific activity of isolated cystine }}
\end{aligned}
$$

3. The method has been applied to insulin, lysozyme and bovine plasma albumin, and has given results in good agreement with the complete structures for the first two proteins and with recent experimental values for the third.

4. Some observations on the stability of cystine in acid solutions are reported.

Thanks are due to Mrs B. Lewis and Mrs E. M. Tiler for their skilful assistance. This work is part of a programme of research sponsored by the Agricultural Research Service of the United States Department of Agriculture under the authority of Public Law 480.

\section{REFERENCES}

Anfinsen, C. B. (1958). In Symp. Protein Structure, p. 226

Ed. by Neuberger, A. London: Methuen and Co. Ltd. Cecil, R. \& Loening, U. E. (1960). Biochem. J. 76, 146. Corfield, M. C. \& Robson, A. (1955). Biochem. J. 59, 62. Fletcher, J. C. \& Robson, A. (1961). Biochem. J. 80, 37 P. Folin, O. \& Marenzi, A. D. (1929a). J. biol. Chem. 83, 103. Folin, O. \& Marenzi, A. D. (1929b). J. biol. Chem. 83, 109. 
Fromageot, C. \& de Garilhe, M. P. (1950). Biochim. biophys. Acta, 4, 509.

Glazer, A. N. \& Smith, E. L. (1961). J. biol. Chem. 236, 416.

Henriques, F. C., Kistiakowsky, G. B., Margnetti, C. \& Schneider, W. G. (1946). Industr. Engng Chem. (Anal.), 18, 349.

Human, J. P. E. (1958). Text. Res. (J.), 28, 647.

Jollès, J., Jollès, P. \& Jauregui-Adell, J. (1960). Bull. Soc. Chim. biol., Paris, 42, 1319.

Jones, A. S. \& Letham, D. S. (1956). Analyst, 81, 15.

Kassell, B. \& Brand, E. (1938). J. biol. Chem. 125, 115.

Kolb, J. J. \& Toennies, G. (1952). Analyt. Chem. 24, 1164.

Kolthoff, I. M., Anastasi, A., Stricks, W., Tan, B. H. \& Deshmukh, G. S. (1957). J. Amer. chem. Soc. 79, 5102.

Kolthoff, I. M., Anastasi, A. \& Tan, B. H. (1958). J. Amer. chem. Soc. 80, 3235.

Leach, S. J. (1960a). Aust. J. Chem. 13, 520.

Leach, S. J. (1960b). Aust. J. Chem. 13, 547.
Lewis, B., Robson, A. \& Tiler, E. M. (1960). J. Text. Inst. 51, T653.

Lewis, J. C., Snell, N. S., Hirschmann, D. J. \& FraenkelConrat, H. (1950). J. biol. Chem. 186, 23.

Piez, K. A. \& Eagle, H. (1956). J. Amer. chem. Soc. 78, 5284.

Ryle, A. P. \& Sanger, F. (1955). Biochem. J. 60, 535.

Ryle, A. P., Sanger, F., Smith, L. F. \& Kitai, R. (1955). Biochem. J. 60, 541.

Schram, E., Moore, S. \& Bigwood, E. J. (1954). Biochem. J. 57, 33.

Shinohara, K. (1936). J. biol. Chem. 112, 683.

Shinohara, K. \& Kilpatrick, M. (1934). J. biol. Chem. 105, 241.

Stein, W. H. \& Moore, S. (1950). Cold Spr. Harb. Symp. quant. Biol. 14, 179.

Thompson, E. O. P. (1955). Proc. int. Wool Text. Res. Conf. Australia, c 102.

Toennies, G. \& Lavine, T. F. (1930). J. biol. Chem. 89, 153.

Biochem. J. (1962) 84, 444

\title{
A Method for Separating Lipid Components of Leaves
}

\author{
By V. H. BOOTH* \\ Dunn Nutritional Laboratory, Milton Road, Cambridge
}

(Received 12 February 1962)

In the separation by paper chromatography of tocopherols or carotenoids and other lipids it is customary to study only one group of compounds and to remove as many as possible of the interfering substances by such pretreatments as saponification or column chromatography. For the study of leaf extracts it was found that these preliminary stages are best omitted. The method is thereby simplified, with consequent reduction in loss of lipids; indeed, in this paper the 'interfering substances' are themselves studied.

The paper chromatograms were developed in the first dimension by adsorption and in the second by reversed-phase chromatography. The technique separated many of the lipids, including known substances such as pigments, vitamins and quinones, as well as fluorescing substances and other unknowns that accompanied chlorophyll.

\section{METHODS}

Small samples of fresh leaf were weighed and extracted repeatedly in the cold (Booth, 1959) with redistilled acetone and light petroleum $\left(30-40^{\circ}\right)$ that had been purified by passing it through aluminium oxide. To avoid enzymic destruction of lipids the extracts must be made quickly (Booth, 1960). The extraction of small samples by grinding with quartz in a beaker was quicker than the extraction of

\footnotetext{
* Member of the scientific staff of the Agricultural Research Council.
}

large samples in a mechanical blender. Acetone was removed by washing with water in an automatic drip wash (Booth, 1957, p. 51), and the light-petroleum solution was concentrated to about $1 \mathrm{ml}$. in a stream of nitrogen gas on a water bath at about $70^{\circ}$.

Chromatographic procedure was based on that of Green, Marcinkiewicz \& Watt (1955) as fully described by the Analytical Methods Committee (1959). For the present work many modifications were developed to shorten the method, or to increase a paper's capacity for lipids. The modifications are included in the following procedure. Whatman no. 31 (et) filter papers, size $22 \mathrm{~cm} . \times 32 \mathrm{~cm}$. with machine direction along the short dimension, were impregnated with zinc carbonate according to Analytical Methods Committee (1959) except that the sodium fluoresceinate was limited to $2 \mathrm{mg}$./1. of the ammoniacal zinc carbonate solution. The lipids were not saponified, but the whole green extract was chromatographed on two papers. Distortion of the spots on the chromatograms was minimized by applying the solution over an area of about $7 \mathrm{~cm} . \times 3 \mathrm{~cm}$. from a modified Trenner pipette (Anderson, 1952) having a curved polished tip and holding about $50 \mu \mathrm{l}$. The papers were mounted on a frame and the chromatograms were developed (ascending) with $1 \%$ acetone in light petroleum $\left(40-60^{\circ}\right)$ in a $35 \mathrm{~cm}$. high tank lined with thick filter paper. After an hour the lipids had separated into bands in the 'corridor' (the left two-fifths of each chromatogram; Fig. 1). The papers were removed from the tank and the clear portions were coated with medicinal paraffin. In the second dimension the chromatograms were developed by the ascending method across the paraffin for about $1.5 \mathrm{hr}$. with methanol-water $(23: 2, \mathrm{v} / \mathrm{v})$. Methanol is hygroscopic and volatile: it was maintained at $92 \%$ by daily addition of pure methanol to the tank. 